\title{
All together now
}

\author{
The decision to site the fusion experiment ITER in France left relatively little bad blood between the \\ international partners, who must now rally behind the project.
}

$\rho^{\prime}$ o ITER - the international fusion-power experiment whose faltering progress sometimes seems to echo that of fusion research itself - may finally be built, after all. The countries involved have agreed in principle that construction should begin in France next year.

No one will question the technical capabilities of the hosts: France has an awesome tradition in nuclear technology, a strong will to make the project happen, and firm backing from the rest of the European Union (EU). A few reservations remain about the technical approach taken in ITER's design (see page 318), but most fusion researchers are delighted that the project looks set to proceed.

Some important details need to be resolved before that happens, however. Funding for the project is still to be lined up by most of the partners, for example, and much of it is likely to come at the expense of other, existing fusion research projects. Broadly speaking, the EU is supposed to pay half of the construction costs, while the other five partners - Japan, the United States, Russia, China and South Korea - pay $10 \%$ each. Additionally the nature of secondary facilities, to be built in Japan, has yet to be determined.

In several member countries, ITER will clash with domestic research priorities. In the United States, for example, the Bush administration has already tried once to shoehorn the $\$ 50$ million annual cost of ITER construction into the existing $\$ 230$ million budget for magnetic fusion research. Sherwood Boehlert, chairman of the House science committee, has rightly warned that this won't wash. If the administration is sincere in its support for a project that the Department of Energy has selected as its top-priority facility, it will allocate extra funds for ITER in its 2006 budget proposal, which comes out in February.

Some in Congress are bound to question support for any international project - especially one in France. But if the US scientific community unites behind the project, then a desire to treat the rest of the world with less than total contempt will prevail in Congress, as happened when a similar amount of money was successfully appropriated over many years for the US contribution to the Large Hadron Collider in Switzerland.

The second issue concerns the types of supporting facilities to be built and their funding. Such projects are likely to include a materials testing centre, a computing centre for data analysis, and an upgrade for Japan's JT-60 fusion experiment. In return for Japan's agreement to drop its bid to build ITER itself, the EU will support Japan in its bid to lead these projects. Japan is best qualified and best equipped to do this. It should step up as a true leader, as it failed to do when pursuing ITER's construction. Other countries should support Japan in this role.

Among these projects, the most expensive - and the most valuable from the point of view of international progress towards fusion energy - would be a neutron source for use in materials testing. The crystalline structure of stainless steels and other metal alloys that might be used in working fusion reactors is expected to deteriorate rapidly under neutron bombardment. In the absence of a test facility that can supply a suitable neutron flux, no one has been able to search for metals or ceramics that might survive this bombardment for the lifetime of a working fusion reactor. Such a facility is needed, alongside ITER, to take magnetic fusion forward.

But progress has been slower than fusion advocates would like. To be fair, there has been a chicken-and-egg aspect to this: investment has been withdrawn from magnetic fusion research when it was most badly needed. Naysayers joke that fusion power has always been 50 years in the future - and always will be. Their scepticism needs to be balanced against the unique and almost boundless potential of fusion, should it be harnessed. Anyone who doubts this potential should try getting up early one morning to watch the sunrise.

\section{Socialism in one country}

\section{Cuba's scientific community has made substantial progress in addressing social problems.}

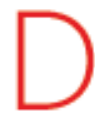
espite a floundering economy, restrictions on free speech and the incessant hostility of its powerful neighbour to the north, Cuba has developed a considerable research capability - perhaps more so than any other developing country outside southeast Asia. Whatever one thinks of its leader, Fidel Castro, it is worth asking how Cuba did it, and what lessons other countries might draw from it.

When Castro came to power in 1959, Cuba had almost no scientific infrastructure. Now it boasts a biotechnology industry that has produced effective drugs and vaccines of its own, a large and fairly influential scientific work-force, and a fledgling pharmaceutical industry with its sights set on export markets. The agricultural sector, in which small farmers benefit from partnerships with agricultural researchers, is also quite successful (see page 322 ).

Some of the reasons for Cuba's success are straightforward. The government has invested heavily in elementary and secondary education, and has attained developed-world standards of literacy and numeracy in its population. After university, large numbers of young scientists are sent abroad for training — once to its Communist allies, more recently to Europe and Latin America - and Cuba ensures, by fair means or foul, that they return home afterwards to work.

But one aspect of Cuba's scientific success is often overlooked. At 
various times, other Latin American nations such as Venezuela and Argentina have sought to build up science and technology by supporting a mixture of pure and applied research, a model similar to that established in wealthier countries. Cuba took a different approach: research there is ruthlessly applied.

Cuba's state-sponsored science is structured like a corporate research laboratory, except that its output consists of social outcomes, rather than commercial products. If a project looks likely to earn foreign currency or meet the government's social objectives, it is backed to the hilt. Cuba's scientists have no funds for basic research, but they largely back their government's approach, in part because they have seen how it transformed health services in their country.

But the approach has many drawbacks. One concerns the constraints that it places on the movement of researchers. Castro's government maintains strict control on the movement of its citizens. Scientists fare better than most, and are frequently allowed to attend conferences or spend time working in foreign laboratories. Yet if they stay away for longer than permitted, they lose the right to return freely. This draconian approach to dealing with the threat of a brain drain is in breach of the Universal Declaration of Human Rights, adopted by the United Nations in 1948. Restrictions on free political expression in Cuba are also inconsistent with the declaration.

It is questionable, in any case, whether such restrictions serve any useful purpose for Cuba's government, given the obvious commit-

ment of the scientists in question to their country's future. Just as questionable is the purpose served by the continuing US trade embargo on Cuba, which continues to isolate scientists and others on the island from their colleagues in the United States, including a large group of Cuban origin.

The embargo damages Cuban science and scientific collaboration in various ways. A Cuban proposal for dengue research, for example, won a $\$ 700,000$ award from the Bill \& Melinda Gates Foundation after international peer review. But the award has been held up for a year, lest the illustrious Microsoft founder,

"Cuba's science is structured like a corporate research lab, except that its output consists of socialoutcomes not commercial products."

his wife and their fellow trustees be dragged off to the penitentiary for breaching the embargo.

Nature has consistently opposed scientific embargos, and strongly believes in research collaboration as a means of building bridges between nations that lack normal diplomatic relations. But there is a more specific issue here. When Castro dies, Cuba faces a period of volatility that could endanger key national assets, such as its science. In preparation for that day, both Havana and Washington should be acting now to wind down such cold-war artefacts as Cuba's travel restrictions and the US trade embargo.

\section{Agency under siege}

\section{Conflicts-of-interest at the US National Institutes of Health justify the agency's ethics crackdown.}

T he latest information to emerge from an investigation by Congress into potentially unethical links between outside companies and researchers at the US National Institutes of Health (NIH) isn't particularly encouraging.

At the request of Congress, the biomedical research agency has been looking into the activities of 81 researchers whose names appeared on lists of consultants provided by biotechnology and pharmaceutical companies, but who hadn't declared their interest to the NIH.

Earlier this month, the NIH's director, Elias Zerhouni, told Joe Barton (Republican, Texas), chair of the House Committee on Energy and Commerce, that about half of the 81 were found to be in breach of the ethics rules that were in force at the time of their consultancy work. Most of the infractions were minor, but eight have been referred to the health department's inspector-general for further investigation.

The steady drip of this sort of information into the public domain since December 2003, when the Los Angeles Times first reported a few egregious examples of conflict-of-interest at the $\mathrm{NIH}$, is taking its toll on the public reputations of the agency and its staff.

Zerhouni has moved swiftly to confront the issue. His clampdown on consultancy arrangements and on the holding of investments among thousands of NIH employees has caused much wailing and gnashing of teeth at the agency's main campus in Bethesda, Maryland.
But the rules are being implemented with extended deadlines to allow people sufficient time to alter their financial arrangements.

The clampdown leaves the NIH's intramural staff in a bind, unable to collaborate closely with the biotechnology industry at a time when such interactions have become almost routine for researchers in some sub-disciplines. At some stage, collaboration between researchers and industry must be redeveloped on a basis that will be consistent with the public's reasonable expectations of publicly funded researchers.

Details of the latest batch of infractions haven't been released, but many of them are probably minor, such as meeting an off-site collaborator without requesting a half-day's vacation. Congress is angry because the interactions weren't properly reported under the NIH's previous ethics regime. In some cases, that happened not out of any nefarious intent, but because the NIH is a large and diffuse federation of centres and institutes.

Now Barton's committee wants to centralize the agency. A draft reauthorization bill for the agency would give far more authority to the director's office, and support additional and extensive monitoring and reporting functions there, as well as giving the director more power to enforce cooperation between institutes and centres.

Some reform is due, but this measure goes too far. The NIH needs to modernize, but shouldn't overthrow the autonomy of centres and institutes that has served it so well in the past.

The eventual solution should involve a mixture of self-awareness and common sense. Researchers need to recognize that the conflictof-interest issue can no longer be brushed off as something for politicians and the press to worry about. The cases that have already been exposed at the NIH amply demonstrate how germane the matter is to biomedical research. 